\title{
Nursing societies in Santa Catarina state (1975-2018)
}

\author{
Sociedades de enfermagem em Santa Catarina (1975-2018) \\ Sociedades de enfermería en Santa Catarina (1975-2018)
}

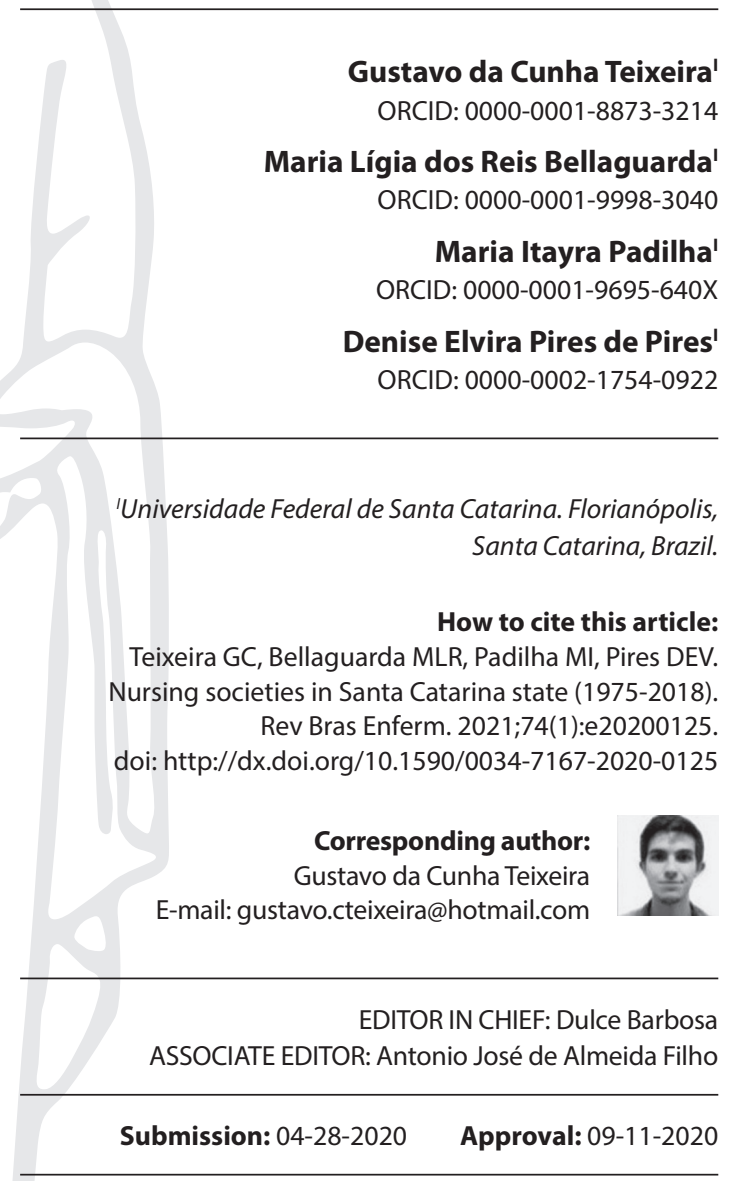

\begin{abstract}
Objectives: to understand nursing representative entities' articulations and the influence on nursing. Methods: a qualitative study of a historical-social approach with a conceptual framework by nurse Denise Elvira Pires de Pires. With a historical profile from 1975 to 2018, five former presidents of Brazilian Nursing Association - Santa Catarina Section and Regional Nursing Board of Santa Catarina were interviewed. The methodology for understanding data was through Bardin's content analysis. Results: the board structuring and performance generated changes in the relations between the two entities and debate about the role and power of representation of each one. There were periods of approach and removal, with consequences for professional representation effectiveness. Conclusions: nursing valuation and recognition as a profession in society has a strong influence on entities' performance that represent it. The union of them, politically or organizationally, is necessary and urgent. Descriptors: Nursing; History of Nursing; Professional Corporations; Sociology; Societies, Nursing.
\end{abstract}

\section{RESUMO}

Objetivos: compreender as articulações das entidades representativas da enfermagem e a influência na profissão. Métodos: estudo qualitativo, de abordagem histórico-social, com marco conceitual da enfermeira Denise Elvira Pires de Pires. Com recorte histórico de 1975 a 2018 , foram entrevistados cinco ex-presidentes das Associação Brasileira de Enfermagem - Seção Santa Catarina e do Conselho Regional de Enfermagem de Santa Catarina. A metodologia de compreensão dos dados se deu através da análise de conteúdo de Bardin. Resultados: a estruturação e atuação do conselho gerou mudanças nas relações entre as duas entidades e debate acerca do papel e poder de representação de cada uma. Verificou-se períodos de aproximação e afastamento, com consequências para efetividade da representação profissional. Conclusões: a valorização da enfermagem e seu reconhecimento enquanto profissão na sociedade tem forte influência da atuação das entidades que a representam. A união das mesmas, de forma política ou organizativa, é necessária e urgente.

Descritores: Enfermagem; História da Enfermagem; Corporações Profissionais; Sociologia; Sociedades de Enfermagem.

\section{RESUMEN}

Objetivos: comprender las articulaciones de las entidades representativas de la enfermería y la influencia en la profesión. Métodos: estudio cualitativo, con enfoque histórico-social, con marco conceptual de la enfermera Denise Elvira Pires de Pires. Con un perfil histórico de 1975 a 2018, se entrevistaron a cinco ex presidentes de la Asociación Brasileña de Enfermería Sección Santa Catarina y del Consejo Regional de Enfermería de Santa Catarina. La metodología para comprender los datos fue a través del análisis de contenido de Bardin. Resultados: la estructuración y desempeño del directorio generó cambios en las relaciones entre las dos entidades y debate sobre el rol y poder de representación de cada una. Hubo periodos de cercanía y retraimiento, con consecuencias para la efectividad de la representación profesional. Conclusiones: la valorización de la enfermería y su reconocimiento como profesión en la sociedad tiene una fuerte influencia en el desempeño de las entidades que la representan. La unión de ellos, política u organizativa, es necesaria y urgente.

Descriptores: Enfermería; Historia de la Enfermería; Corporaciones Profesionales; Sociología; Sociedades de Enfermería. 


\section{INTRODUCTION}

To transform the future, it is necessary to know the past. When analyzing the history of a profession, it is known not only how it has shaped itself through the ages, but also the directions to which it is headed. Through historical study it is possible to revisit, recognize and value people and their actions in the struggle to gain space for a profession ${ }^{(1)}$.

Nursing has an ancient history. However, from the middle of the $19^{\text {th }}$ century, with the works of Florence Nightingale, it is possible to identify the bases that structure nursing as a profession ${ }^{(2)}$.

Considering the Sociology of Professions precepts and taking the concepts formulated by Pires ${ }^{(3)}$, it is possible to state that nursing has been building its own course, taking care as its epistemological object. Throughout history, producing knowledge that underlies them has been adding to the relevant care practices, nurses have assumed the responsibility of training new professionals, as well as formulating and defending the legal and ethical requirements required for professional practice. Nursing professionals develop work in the health field, mostly institutionalized and involving teams; a work and whose final product is produced and consumed in an inseparable process ${ }^{(3)}$.

Following the adopted theoretical perspective, it is also important to highlight the role of legislation and professional regulation as well as the relevance of organizational entities' performance in the representation of nursing in society. Such entities, organized separately or in a unified structure, represent nursing's interests in society, regulate professional practice and develop actions to strengthen respect for professional expertise and ethical precepts, which contributes to constructing autonomy ${ }^{(3)}$.

In Brazil, the history of nursing representation entities has a strong relationship with nursing structuring. When the first group of nurses graduated, one of the oldest nursing schools in Brazil, the School of Nurses of the Brazilian National Department of Public Health (EE/DNSP), currently Escola de Enfermagem Anna Nery (Anna Nery School of Nursing), the first organizational entity was born, which subsequently, after various changes in structure and name, it was established as Associação Brasileira de Enfermagem (ABEn - Brazilian Nursing Association) in $1954^{(4)}$. ABEn is organized into state sections in order to strengthen representation and promote closer ties with the reality of each region of the country; thus, ABEn - Santa Catarina Section emerges in $1962^{(5)}$.

After 30 years of struggles and discussions, nursing conquers the creation of a supervisory body for professional practice. The Federal Nursing Board (COFEN - Board Federal de Enfermagem) was established in 1973, with this supervisory role and being an ethical court. COFEN creates and regulates the Code of Ethics for nursing and acts by approving a Professional Practice Law that updated Law 2604 of 1955 then in force ${ }^{(6)}$. In 1986, Law 7498 was approved, which established parameters for inspection and authorization for professional practice. In Santa Catarina, the Regional Nursing Board (COREN - Board Regional de Enfermagem) was created in 1975, thus becoming the most complex representation. At this point, ABEn's historical roles were divided. However, what started with an achievement soon had repercussions for the Brazilian nursing organization.

Based on the above, the following question arises that guided the research: how did organizational entities influence the nursing profession?
It is understood that a valued profession is strong before society. The union of the category, then, is a prime factor for taking actions capable of guaranteeing the space of nursing within health, in defense of people's rights to safe and quality care.

\section{OBJECTIVES}

To understand nursing representative entities' articulations and the influence on nursing.

\section{METHODS}

\section{Ethical aspects}

This study follows the ethical precepts of Resolution 466/2012 of the Brazilian National Health Board (CNS - Board Nacional de Saúde), being approved by the Research Ethics Committee with Human Beings (CEPSH) of Universidade Federal de Santa Catarina (UFSC). Participants signed the Informed Consent Form and an Interview Assignment Term. As it is a historical research, the interviewees' real names were used as they are key pieces for the interpretation of the context of their statements.

\section{Type of study}

This is a qualitative study with a historical-social approach, which used SRQR to build this methodology. This methodology aims to revisit past facts issues from the interviewees' perspective. It allows analyzing what is said and what is not said, in addition to making a critical reflection of all issues experienced in counterpart to the current reality experienced ${ }^{(1,7)}$.

\section{Methodological procedures}

This study was developed internally with the representative entities of nursing. Five former president nurses of ABEn-SC and COREN - SC were interviewed in the historical section of 1975 to 2018, respectively the process of creating COREN - SC, and the current year of the beginning of the research. To systematize data collection, time frames were included: 1975, creation of COREN in Santa Catarina; 1980, "Participatory" Movement appearance in Santa Catarina; 2008, the year in which the Participation Movement takes over COREN - SC administration.

Former presidents and/or member of the board of directors of representative entities within the defined historical outline were included. People unable to communicate and express themselves, due to health problems, death were excluded.

\section{Data collection and organization}

Data collection took place through oral history of study participants, with 5 former presidents being interviewed by semi-structured and digitally recorded script. Availability of the time and place chosen by interviewees was respected and data collection started after approval by a Research Ethics Committee. The interview time averaged 45 minutes. Interviewees' recording was transcribed and later transcribed. 


\section{Data analysis}

An assessment was initiated through Bardin's content analy$\mathrm{sis}^{(8)}$. The three recommended phases were strictly followed: Preanalysis, consisting of data organization and exhaustive reading; Exploration, continues with code identification; and Treatment of results, in which codes were organized in an analysis grid, in order to compose the analytical categories of the research.

To guide the interpretation of results, Pires' formulas ${ }^{(3)}$ were used as a Conceptual Framework, following the concepts of nursing as a profession, course and work.

\section{RESULTS}

In this stage of the research, four categories were identified, which, because it is a historical research, are analogous to different periods of development of the entities representing nursing: Pre-creation period of the board; Period of birth, sharing and structuring; Representative maturation period; Current period: representation today and tomorrow.

\section{Pre-creation period of the board}

Professional organization of Brazilian nursing has its first milestone from the first class of nurses trained in Brazil, with the creation of Brazilian National Association of Registered Nurses (ANED - Associação Nacional das Enfermeiras Diplomadas).

The need to create an association was a priority at that time. This is mainly due to the Technical Mission of Cooperation for Nursing Development. Also known as the Parsons Mission, it aimed to implement modern nursing in Brazil under the leadership of Mrs. Ethel Parsons. For this, it was necessary to create a nursing school, to be consolidated as a profession. It was also necessary to create a representative entity and a journal. In other words, it consisted of generating space for the maintenance of professional autonomy and the dissemination of scientific nursing knowledge $\mathrm{e}^{(9)}$.

Throughout nursing development, ANED, which was renamed to ABEn in 1954, remained, throughout the period, the only Brazilian entity with representative power for nursing. To get closer to the body it represents, it was capillarized through sections in the most diverse states, with the Santa Catarina Section created in 1962 under the presidency of Sister Cacilda (Nurse Ottillie Hammes).

But we didn't have a body that would take care of our category, although ABEn did that there. ABEn did it very well. (Rosita Sauppe)

We did not have a COREN presence, so here in Santa Catarina, who dominated the environment and the representation of nursing in this period was markedly ABEn. ABEn had social recognition as well. (Jorge Lorenzetti)

ABEn was the most important entity, most representative of nursing, it already played this role as a unitary entity, despite having union entities, but it did not have a nurses' union and it did not have a Federal Board or a Regional Nursing Board. (Denise Elvira Pires de Pires)

However, a dilemma was faced for broad nursing development. While ABEn kept its representative role, it was not assigned the legal right to register professionals, i.e., credentialism. Ensuring that nursing was exercised only by those that the peers considered fit was a huge challenge ${ }^{(10)}$ recognized by ABEn.

Nursing took 30 years to get their board. Until then, ABEn has always captained all advances in nursing. (Rosita Saupe)

The board was born because of ABEn's work. (Ingrid Elsen)

COFEN was born as a result of broad discussion and debate of the category. The need for a professional inspection body was solved in 1973, with its creation.

\section{Period of birth, sharing and structuring}

With the approval of Law 5.905/73, the COFEN-COREN system is created, placing in the agenda the need to operationalize what would become the future entity. The construction role was then absorbed by ABEn, with each state section responsible for meeting the requirements for installing the board in its region ${ }^{(11)}$.

The first problem encountered was the dichotomy related to its creation. Despite the discussion previously held within the association, there were still questions about what the new entity's real roles would be with regard to representation and its relationship with $A B E n^{(5)}$. This issue was mediated by legal limits and by urgency of time.

I think that we had to protect our class, make sure that nursing was performed by qualified people. Who had that training, who had that authorization. (Rosita Saupe)

ABEn was for meetings, parties, congresses. So, it was freer. It could unite with helpers, unite. ABEn was much freer. Not the board, the board came with many strict things. The board comes with many things above nursing, that is things required by law. (Ingrid Elsen)

This was a structure that was not necessarily created by nursing. In the sphere of society, the issue regarding the role of boards was being raised. (Denise Elvira Pires de Pires)

The definition of roles made it necessary for an initial period to establish the entity's, its board's and general structure's objectives. Thus, initially, ABEn's and the board's work takes place in a similar way, with a mutual support relationship between the entities.

Of course, each one has its role, but the bigger role is practically the same, we want the good of nurses for the good of nursing actions, nursing care. (Ingrid Elsen)

It was a "honeymoon" time. There were hospitals, there were sisters in hospitals. Everyone wanted the same thing. (Rosita Saupe)

There was no conflict between COREN and ABEn. There was no conflict that came later. (Jorge Lorenzetti)

In this first post-creation period of the entity, the board starts to play its supervisory role. The registration of professionals, carrying out the category census and recognition the need for professionalization of nursing attendants are marked as milestones, which became more effective after the approval of Law 7498/1986. 
I think it registered everyone, so we already had a census, right? It was the great nursing census. It qualified with these years, and maintained an integration, a very close relationship with all the people who had some interest with the university, with other boards, with COFEN, with other regional boards. (Rosita Saupe)

\section{Representative maturation period}

The years that followed the board's creation brought profound changes in the relations between the representative entities. Changes such that marked the difference in their performance and the paths that each would follow.

While we worked to create the board, we were very close. After he was created, in the beginning, it always worked with [...] very good communication. There are many candidates, so everything is very complex, right? You get along with some. Some like you, there are others who don't like you, then things got very strict. (Ingrid Elsen)

The first key point was the strengthening of the board's economic power. Despite starting gradually, the registration of nursing professionals, to exercise their function, is mandatory. The result of the expansion in training new professionals and the way of registering them brought exponential economic growth for COFEN ${ }^{(5)}$.

The first problem I started to see was when people had to pay. They didn't know, nobody knew that they had to pay, so we had to charge people. (Rosita Saupe)

On the other hand, the association remains in its system of voluntary association and gradually decreases its financial resources and, consequently, its power of professional representation, previously historic. Despite this, the explanation for reducing the number of members is more complex.

ABEN was the only body that moved the whole of Brazil. So, I think the board owes ABEN that, and I shouldn't forget, but I think the board went on its way and ABEN that was a little more weakened. (Ingrid Elsen)

Thus, a different path for the two entities begins. Different struggles from inner nursing are initiated, influenced by the political, legal and institutional scenario of Brazil.

In the 1980s, with more than 15 years of Military Dictatorship, the discussion about redemocratization emerges with greater force. In universities, schools and organizations representing workers and various members of society, there is an effervescent debate about their role and the alignment, or not, that they should have with the current government ${ }^{(11)}$.

This scenario has an influence on nursing and promotes the birth of a national movement within ABEn called "Participatory" Movement (MP - Movimento Participatório). MP was built with a significant participation of nursing leaders from Santa Catarina, having as flags the defense of democratization of ABEn and Brazilian society, profession valuation and the universal right to health. The people who made up this picture maintained the belief that it was necessary to build a strengthened and critical $A B E n$, and not only reproducing current government policies ${ }^{(11)}$.
In 1980, MP's electoral alliance was elected to the direction of ABEn - Santa Catarina, representing a significant change in its direction and in relations with the government ${ }^{(11)}$. The number of members is expanded exponentially and the participation of the category in ABEn's daily life supports the flags in defense of profession valuation ${ }^{(11)}$.

This debate expands nationally, and, in the 1984 election, MP organizes electoral alliances across the country, running for elections for the sections and national board of ABEn. The process did not take place without trauma, involving election annulment and a new election in 1986 with a broad victory by MP.

Conversely, COFEN became more bureaucratic and distanced from the category. The problems worsened in the 1990s and following years, including serious deviations in COFEN's, private appropriation of the entity's resources and persecution of opponents. Too quickly, COFEN distances itself from the struggles of the category, abstaining in several spaces for the defense of nursing and working conditions ${ }^{(11)}$.

This period of the 1990s and the first decade of 2000, despite growing and strengthening the democratic ideas of $A B E n$, at the same time a highly conservative movement within the Federal Board of Nursing and the Regional Boards grew. Until a point reached that this conservative and authoritarian idea of the Federal Board of Nursing became hegemonic throughout Brazil. (Denise Elvira Pires de Pires)

The strict attitude of the board's administration culminated, in contrast, with an opposition movement that was also increasingly strengthened and organized. With support from ABEn, denunciations against irregularities and the policy in force at the board are intensified ${ }^{(11)}$.

While there is the importance of struggle to reorganize the board, there is also the aggravation of distancing of entities, with a consequent decrease in the political role of nursing in social interventions and the discredit of the entities by professionals. This scenario resulted in a weakening of the struggle for professional development ${ }^{(6,11-12)}$.

So, the scenario we found at that time was a scenario of great tension between the two entities, and the main tension was not due to professional issues. It was the political issue of the way the board was, that the board directors were appropriating the entity. No, they were appropriated nationally and here in the state this was reproduced. (Denise Elvira Pires de Pires)

One of the serious problems we have with the difficulties of devaluation in nursing is our fragmentation of representation. (Jorge Lorenzetti)

The movement to oppose the practices and politics in force in the COFEN/COREN system reached its peak in Santa Catarina during the 2008 election. to the CORENs. The electoral process in the system was governed by strict and bureaucratic national legislation, making the registration of new electoral alliances very laborious and making it difficult for opponents to participate in the process. In Santa Catarina, three electoral alliances competed, only one opposing and identified with MP's ideals. There were several attempts to try to stop the approval of MP's electoral 
alliance, however, provided with strong legal advice and an ideal. The movement's representative electoral alliance wins the 2008 elections, under the presidency of Denise Elvira Pires de Pires ${ }^{(11)}$.

Furthermore, it is noteworthy that the electoral alliance organization and the victory of MP were possible due to the alignment with the board of ABEn - SC, the strong mobilization of nursing in the state and the debate in society involving institutions such as the Legislative Assembly, Ministry Federal Public and several professional and union organizations in the health area. Under the presidency of Helga Regina Bresciani, there was institutional support from ABEn - SC in the conquest of this space to add to the struggle for profession valuation, consisting of a first movement of political realignment among the representative entities of nursing in the state.

No, ABEn and COREN at the time, in the previous administration [to 2008], we did not agree, we had difficulties talking. We did not do joint fights. For that, we fought to change. (Helga Regina Bresciani)

\section{Current period: representation today and tomorrow}

The reflexes of the election of MP for the administration of COREN - SC are soon observed in the scope of professional representation. A process of openness and political participation of COREN - SC begins with the flags of nursing within its legal limits. Just like the first years of the board's appearance, the entities once again have the necessary alignment to articulate their struggles ${ }^{(11)}$.

However, nationwide, there is still a way to go in the political articulation of the two entities and in strengthening them. Through interviewees' statements, it is clear that the results of the fragmentation of national representation, verified since the 1970s, still persist today.

We see that, unfortunately [...] since the 1990s, ABEN has lost a lot of representativeness. How much does ABEn represent today? How much are members of ABEN? So, it is poor. This representation is almost symbolic. It is more historical, from the past, than from the present. (Jorge Lorenzetti)

I think $A B E n$ continues to fight. ABEn is weakened by the number of people, in fact. (Helga Regina Bresciani)

This reflects in an old struggle of MP, the unitary entity, as a way to overcome the fragmentation experienced ${ }^{(5)}$.

One of the issues that we thought weakened nursing and the achievements in terms of working conditions was the division between the entities. Transform each of them into an organization that represented certain aspects without them sitting [to debate]. (Denise Elvira Pires de Pires)

We wanted to have a unitary entity to defend the interests of nursing, and we see how bad that [didn't happen], in my opinion, was bad for nursing. [...]. Today, we have almost 2 million nursing professionals. If we had a representative entity that could bring together professional interests, but also the interests of work, working hours, salary claims, all that, and minimum salary. All of this in an entity that has this weight, which is the largest group of health professionals in Brazil. The strength that this entity could have, right? (Jorge Lorenzetti)
It is important to note that the unitary entity is not the only way to overcome historical differences between entities that respondents raised. Local and other country experiences are also presented.

[In Netherlands] they had an organization that even maintained different structures, they had one that spoke for nursing, that spoke for medicine, when it came to defining public policies. (Denise Elvira Pires de Pires)

I think we have been talking about a single entity for the defense of nursing for a long time, but when we speak only, it does not mean a single National Register of Single Entities. Unique that we fight for the same things, association, board and nursing union. (Helga Regina Bresciani)

At the time, our vision was to transform ABEn into a unitary entity. Doctors have a board. A board of medical entities, board with regulations and everything. (Jorge Lorenzetti)

\section{DISCUSSION}

ABEn, since its inception, has played an important role in structuring nursing as a health profession. During its first decades, it grew in strength, assuming profession representation in society, the definition of standards for ethical conduct and the inspection of the exercise, in addition to the formulation of rules for professional training ${ }^{(11)}$. Through ABEn, the dissemination of knowledge produced by Brazilian nursing is also strengthened. In 1939, two uniquely important commissions were created, the Education and Legislation Commission.

Internal to the Education Commission, the nurses who directed the entity sought to improve the knowledge needed to become a nursing professional, initiating a program for the expansion of vocational schools throughout Brazil. It is noteworthy that the expansion of teaching/schools has a direct impact on nursing. Schools that train new professionals and encourage producing knowledge necessary to build a course in the field of science that takes care as an epistemological object. The school has a fundamental role in constructing, discussing and improving the nursing course $\mathrm{e}^{(3,13)}$.

The Legislation Commission has an important role in the debate and formulation of parameters for the definition of laws that support professional practice. Among his most notable achievements, efforts to conquer the first law of professional practice in the country, Law 2,604/55, are mentioned in a victorious process that managed to unite nurses and midwives ${ }^{(13)}$. In the same sense, it played a fundamental role in the formulation of what is established in the current law of professional nursing practice, Law 7498/1986. These actions stand out for their regulatory nature, which is fundamental in professional construction. Entities formed by peers play an important role in the self-regulatory process ${ }^{(14-15)}$.

Another achievement of ABEn, important for nursing, was its contribution to the creation and structuring of COFEN and COREN. COFEN and CORENs comprise a system whose main objective is to monitor professional practice and an ethical court. It is an autarchy that registers nursing professionals and gives them the guarantee to $\operatorname{act}^{(11)}$. 
However, the creation of the board also provided a first period of disarticulation and representative fragmentation that contributed to the weakening of ABEn before society. The situation that included a reduction in $A B E n$ representation and boards acting in a distant way from professionals' desires occurred nationally, in Santa Catarina and in the other states of the federation, directly reflecting in profession valuation before society and in the confidence of professionals in relation to representative bodies.

Nursing valuation is the main theme of the day with regard to professional objectives. The devaluation process is expressed in decision-making spaces of society and health, with consequences for care production and for workers' physical and mental health ${ }^{(12)}$. Valuation is not earned, and only achieved with union of the category. Such a union may start in several ways, but it needs the political alignment of the representative entities.

Constructing a unitary entity is consolidated as a basic way of basing the fight flags and nursing's political positions. It also reflects, in greater power of representation nationally and internationally. It is emphasized that the process for building such a unitary entity is not unison and that many variables must be considered. In addition to the legal process of changing the nature of both entities, there is a concern with maintaining their roles from the point of view of Sociology of Professions. It is necessary to encourage producing and disseminating nursing knowledge, through schools, research in different care spaces and the availability of journals, a work in which ABEn stands out. Moreover, maintaining the function of self-regulation of professional practice carried out by the boards is necessary for care qualification and safety for professional autonomy ${ }^{(4-5,15)}$.

In Brazil, there are examples of entities that remain unique, such as the Brazilian Bar Association (OAB - Ordem dos Advogados do Brasil), which has the power of professional regulation as well as scientific discussion ${ }^{(11)}$, despite the most recent emergence of lawyers' unions dealing with labor negotiation.

Another way of organization mentioned by the interviewees would be through the creation of a "board" of the nursing entities. It would thus be a space for decision between the bodies with representative power of nursing. Through this format, the entities meet without legal changes in their structure, but building a regiment, or statute, that regulates their decision-making space and representation format. It is considered a political-organizational overcoming of aligning nursing's interests.

It is noteworthy that such format of organization has as a positive point the possibility of absorption of the unions that represent nursing, whose role was not the object of this study. Such unions come in various forms, such as those representing all health professionals, even those who deal only with nurses.
However, the higher board opens a gap for its fission depending on those who are elected to the board of the separate entities.

The entities' board format provides national and international examples. The Dutch model of a board between nursing entities is mentioned and, in Brazil, the creation of the Superior Board of Medical Entities (COSEMESC - Board Superior das Entidades Médicas), an organ that brings together the various representations of medicine.

In addition to the forms of organization involved in structural and bureaucratic changes, there is political alignment as a base factor for professional development. The union of struggles and flags brings greater renown to nursing before society and credibility of workers with the entity they are represented. More laboriously, political alignment is always subject to the ideals of elected political representatives ${ }^{(2)}$.

\section{Study limitations}

The limitation of this study is found in two main factors: first, it analyzes specific historical periods and reflects on them to understand the current scenario, but it does not have the scope of professionals' perceptions not linked to the representative entities, generating a vision in a unilateral analysis perspective; the second brings a discussion about the possibilities of uniting the category, however it does not focus on discussing the potential and weaknesses of each one presented.

\section{Contributions to nursing}

The research aims to contribute to reflect on the power of influence of nursing entities for nursing and incite debates on the best strategies for strengthening them. Thus, aiming at the empowerment of nursing before society.

\section{FINAL CONSIDERATIONS}

Nursing is a profession, legal and self-regulated, assuming its own field of knowledge centered on an epistemological object; and, as work, inserted in the health field, it meets a social need.

These characteristics are inseparable; however, the fragmentation of professional representation weakens nursing, hinders its valuation and expression in society. Thus, the importance of dialogue and construction of unity in defense of nursing is reaffirmed, whether from a political point of view or through administrative concatenation.

In this regard, there is an urgent need for studies detailing the forms of professional organization, its strengths and weaknesses, in order to foster the internal debate of entities in a decision to follow the best paths of professional recognition and valuation.

\section{REFERENCES}

1. Padilha MI, Bellaguarda MLR, Nelson S, Maia ARC, Costa R. O uso das fontes na condução da pesquisa histórica. Texto Contexto Enferm, 2017;26(4):1-10. doi: 10.1590/0104-07072017002760017

2. Costa R, Padilha MI, Borenstein MS, Moreira AR. Florence Nightingale (1820-1910): as bases da enfermagem moderna no mundo. In: Padilha MI, Borenstein MS, Santos I. Enfermagem: história de uma profissão. 2. ed. São Caetano do Sul, São Paulo: Difusão Editora; 2015. P. $183-218$.

3. Pires DEP. A enfermagem enquanto disciplina, profissão e trabalho. Rev Bras Enf, 2009;62(5):736-744. 
4. Santos JFE, Santos RM, Costa LMC, Almeida LMWS, Macêdo AC, Santos TCF. Importância das organizações civis de enfermagem: revisão integrativa da literatura. Rev Bras Enferm, 2016;69(3):610-618. doi: 10.1590/0034-7167.2016690326i

5. Bellaguarda MLR, Padilha MI, Pires DEP. Conselho Regional de Enfermagem de Santa Catarina (1975-1986):importância para a profissão. Texto Contexto Enferm, 2015;24(3):654-61. doi: 10.1590/0104-07072015003750013

6. Franco Coffre JA. Percepción social de la profesión de enfermería. Enferm Actual Costa Rica. 2020;0(38):272-81. doi: 10.15517/revenf. v0i38.36930

7. Chizzoti A. Pesquisa em ciências humanas e sociais. 2.ed. São Paulo: Cortez, 2018.

8. Bardin L. Análise de conteúdo. Lisboa, Portugal: Edições 70, 2016.

9. Dias MO, Souza NVD, Penna LHG, Gallasch CH. Percepção das lideranças de enfermagem sobre a luta contra a precarização das condições de trabalho. Rev Esc Enferm USP. 2019;53:1-8. doi: 10.1590/s1980-220x2018025503492

10. Lage CEB, Alves MS. (Des)valorização da Enfermagem: implicações no cotidiano do Enfermeiro. Enferm Foco, 2016;7(3):12-16. doi: 10.21675/2357-707X.2016.v7.n3/4.908

11. Mancia JR, Padilha MI, Ramos FRS. A Associação Brasileira de Enfermagem. In: Padilha MI, Borenstein MS, Santos I. Enfermagem: história de uma profissão. São Paulo: Difusão Editora; 2011. P. 459-82.

12. Pires DEP, Lorenzetti J, Albuquerque GL. O“Movimento Participação” na Associação Brasileira de Enfermagem (ABEn):História e desafios na representação profissional. In: Padilha MI, Borenstein MS, Santos I. Enfermagem: história de uma profissão. 2.ed. São Paulo: Difusão Editora, 2015. P. 459-482.

13. Bellaguarda MLR, Padilha MI, Peres MAA, Paim L. Enfermagem Profissão: seu status, eis a questão. Rev Enferm UERJ, 2016;24(2):1-5. doi: 10.12957/reuerj.2016.8591

14. Carvalho AC. Papel da ABEn na formação do enfermeiro. In: Carvalho AC. Associação Brasileira de Enfermagem 1926-1976. Brasília: ABEn Nacional, 2008. P. 132-7.

15. Pires DEP. Reestruturação produtiva e trabalho em saúde no Brasil. São Paulo: Annablume, 2008. 